\title{
REACTIVE OXYGEN RADICALS - THE THERAPEUTIC EFFECTIVENESS OF ANTIOXIDANTS
}

\author{
Marta Skiba, Agnieszka Pedrycz, Beata Cichacz
}

Department Histology and Embryology, Medical University in Lublin, Poland

\section{ABSTRACT}

Oxidative stress occurring in cells is a consequence of an excessive activity of reactive oxygen forms, resulting from an imbalance between the release of free oxygen radicals and their removal from the cell by antioxidant systems. $90 \%$ of reactive oxygen radicals emerge in mitochondrial respiratory chain during an incomplete four-electron oxygen reduction. The remaining $10 \%$ originate from different reactions occurring in the cell. The established compounds are characterised by a short half-life and are highly reactive. Sparse quantities of free oxygen radicals have a positive effect on cell functions. Oxidative stress leads to damage in cellular membranes, enzymatic and non-enzymatic proteins, as well as DNA. Therapy with antioxidants as exogenous dietary supplements aims at preventing or reducing the risk of development of diseases involving the presence of the oxygen radicals. Whether the antioxidant therapy will bring positive or negative effects depends on numerous factors that need to be considered before their inclusion in the applied treatment. Key words: oxidative stress, free radicals, antioxidants.

ARTICLE INFO

PolHypRes 2016 Vol. 54 Issue 1 pp. 41-48

ISSN: 1734-7009 elSSN: 2084-0535

DOI: $10.1515 / p h r-2016-0006$

Pages: 8 , figures: 0 , tables: 0

page www of the periodical: www.phr.net.pl

Publisher

Polish Hyperbaric Medicine and Technology Society
Review article

Delivery date: $20.12 .2015 r$

Date of approval for print: 22.01.2016r. 


\section{INTRODUCTION}

In order to ensure the correct functioning of a cell, a proper energy supply needs to be ensured for the numerous processes that take place in it. To a large extent a cell receives energy through oxygen respiration, which takes place in mitochondria. Within mitochondrial chains, thanks to electron transporting proteins, oxygen molecules are reduced to water. Since this is an exoergic reaction, it generates energy that may later be used by the cell for other processes.

An oxygen molecule is not always subject to complete four-electron reduction. If it is reduced by less than four electrons, molecules containing at least one unpaired electron in the external electron cover will emerge - reactive oxygen species (ROS). The ROS include not only free oxygen radicals but also compounds that are capable of their generation. The reactive oxygen species are: peroxide radical $\left(\mathrm{O}_{2}{ }^{*}\right)$, ozone $\left(\mathrm{O}_{3}\right)$, hydrogen peroxide $\left(\mathrm{H}_{2} \mathrm{O}_{2}\right)$ and hydroxyl radicals $\left(\mathrm{OH}^{*}\right)$. Reactive nitrogen products include: nitrogen oxide (NO), nitroxyl (NO-), nitrosonium $\left(\mathrm{NO}^{+}\right)$, S-nitrozotiole (RSNOs), peroxynitrates (OONO-) and iron nitrosyl complexes [1].

All of them are highly reactive and characterised by a short half-life, with an aim of achieving electron pairing by donating or obtaining them from other molecules. They react in a non-specific manner with cell components, thus causing their modification and damage. Nearly $90 \%$ of them emerge in the respiratory chain, whereas the remaining $10 \%$ are generated through: oxidase-catalysed reactions, P-450 cytochrome, hydroxylation processes of certain xenobiotics, ionising radiation, transition metal ions, environmental pollutants and many other factors [2].

\section{THE ROLE OF OXYGEN RADICALS IN AN ORGANISM - CHANGES OCCURRING IN PROTEINS}

The oxidative changes in proteins caused by free radicals and reactive oxygen and nitrogen forms include: generation of protein hydroperoxides, hydroxylation of aromatic and aliphatic amino acid residues, nitration of aromatic amino acid residues, oxidation of $-\mathrm{SH}$ groups, oxidation of methionine residues, transformation of certain amino acid residues into carbolynic derivatives, fragmentation of polypeptide chains or formation of cross bonds [3].

In the conditions of homoeostasis, ROS released in physiological quantities play a positive role in a cell: participate in protein phosphorylation, gene expression regulation and elimination of micro-organisms. Nitrogen monoxide and hydrogen peroxide take part in cellular signalling, their high concentrations leading to apoptosis, whereas low concentrations lead to cellular proliferation [4]. Moreoever, reactive oxygen forms play a significant role in immunology. Granulocytes, monocytes and macrophages use them through the phenomenon of the so-called "oxygen explosion" to eliminate pathogens.

The name results from an increase, by a few dozen times, of oxygen consumption occurring during this process. In consequence, large quantities of superoxide anion radicals are generated $\left(\mathrm{O}^{*}\right)$. Moreover, ROS have an effect on lymphocyte $\mathrm{T}$ activation and induction of leukocyte adhesion molecules to endothelium, enabling their permeation from the circulatory system to the locations of inflammatory reaction [5]. Moreover, the role of oxygen radicals in the production of cytokins has been described. The older the mitochondria, the greater the phenomenon of "electron leakage in the respiratory chains" and the generation of free radicals. An excess of free radicals has a destructive effect: it leads to the damaging of structural elements of a cell, and then to its death due to apoptosis of nercosis [6].

Oxidative stress occurring in the cells, is a consequence of an excessive activity of reactive oxygen forms, resulting from an imbalance between the release of free oxygen radicals and their removal from the cell by antioxidant systems [7].

Its cause may be sought not only in the increase in the production of reactive oxygen forms, but also in the deficiency of low-molecular antioxidants, and an earlier deactivation of antioxidant enzymes. Oxidative stress involves damaging of proteins, nucleic acids and lipids. If cellular proteases cannot keep up with the disposal of deactivated and damaged proteins, protein aggregates are formed. The accumulation of protein aggregates occurring in the process of protein damage by oxygen radicals and their derivatives plays a role in the pathogenesis of neurodegenerative diseases (Alzeheimer's, Parkinson's disease) [8].

\section{THE EFFECT OF OXYGEN RADICALS ON} NUCLEIC ACIDS

When subject to oxidative stress, the nitrogen alkali in the molecule of deoxyribonucleic acid, deoxyribose, becomes modified and phosphodiester linkages of nucleotides are ruptured [9]. The mitochondrial DNA, due to its proximity to mitochondrial respiratory chains, is more susceptible to ROS-induced damage.

A hydroxyl radical leads to damage of both purine and pyrimidine molecules of the DNA chain. A multiple modification of the genetic material leads to mutagenesis, carcinogenesis and ageing [10].

\section{THE EFFECT OF OXYGEN RADICALS ON} LIPIDS

Lipids are subject to peroxidation carried out in three phases: initiation, propagation and termination. The factors responsible for initiation are: hydroxyl, hydroperoxide, alkyl radicals as well as nitrogen oxide and dioxide. In this phase, a hydrogen molecule is separated from a molecule of an unsaturated fatty acid constituting a component of cellular membrane - phospholipid. In the period of propagation, with the help of alkyl and oxygen radicals, fatty acid peroxides are created.

Termination may occur between two alkyl, peroxide or two different radicals present in the system. This leads to lipid damage and modification [11]. The physical characteristics of cellular membranes are changed, the activity of membrane enzymes and transporting proteins becomes inhibited.

\section{Characterisation OF PARTICUlaR OXYGEN RADICALS}

The most reactive ROS occurring in biological systems include: hydroxyl radical $\left(\mathrm{OH}^{*}\right)$ and superoxide radical $\left(\mathrm{O}_{2}^{*_{-}}\right)[12]$.

Superoxide radical is believed to be the primary 
radical, which produces secondary oxygen radicals by entering into reactions with other molecules. It is generated as a result of one-electron oxygen reduction. Superoxide radical oxidises cystein, thus leading to a change in protein conformation and their biological properties. Enzymes with active metal molecules in their centres are also exposed to a change in their activity due to the capability of a superoxide radical to oxidise transition metals [12].

The hydroxyl radical emerges as a result of water radiolysis or Fenton reaction using as a substrate hydrogen peroxide and reduced forms of copper or iron cations. It may also be generated in the effect of the HaberWeiss reaction, i.e. the reaction of hydrogen peroxide with superoxide radical. It is thought to be the most common mediator in protein damage [11].

Due to its double role as a reducer or oxidiser the hydroxyl radical can be both an oxygen donor and acceptor. This molecule is not highly specific in terms of its substrates; it can react with all other molecules in the cell. The hydroxyl radical oxidises sulfhydryl groups and damages proteins through oxidation of amino acid residues, damages DNA and unsaturated fatty acids. In the brain, the hydroxyl radical inhibits the activity of monoamine oxidases (MAO-A, MAO-B), enzymes responsible for the catabolism of such neurotransmitters as dopamine, noradrenaline, serotonin [13].

The main initiator of lipid peroxidation is a protonated version of the superoxide anion radical - the hydrogenperoxide radical $\left(\mathrm{HO}_{2}{ }^{*}\right)$. It quickly reacts with negatively charged compounds, and at the same time is easily diffused through membranes.

Moreover, the result of a reaction between nitrogen oxide and superoxide ions is the highly reactive peroxynitrite (ONOO*). This substance is responsible, among other things, for the inhibition of fibrinogen, plasmin and tissue factor [3]. The enzyme - nitric oxide syntase NOS - is responsible for producing nitrogen oxide. Damage to the cellular membrane results in the growth of intracellular calcium concentration and NOS activity.

\section{DEFENCE MECHANISMS AGAINST FREE}

\section{RADICALS}

The exposure to free oxygen radicals and their derivatives has forced the organism to work out certain defence mechanisms. We may divide them into: preventive mechanisms, repair mechanisms and antioxidant protection [10].

Preventive mechanisms consist in the prevention of an occurrence and interaction of reactive radicals with cellular components or an interruption of free radical chain reactions [14]. Repair mechanisms involve the repair or removal of damaged cell components. The inactivation of reactive radicals is performed by smallmolecule antioxidants.

These are compounds supplied to the organisms, such as vitamin $\mathrm{C}, \mathrm{E}$, coenzyme $\mathrm{Q}$ carotenes, gluthathione and trace elements. A greater protective efficiency against ROS is manifested by enzymatic antioxidants, also known as large-molecule antioxidants. Such substances include: catalase (CAT), gluthathione peroxidase (GPx), gluthathione reductase (GRd), superoxide dismutase (SOD) [12].

Superoxide dismutase plays the main role as an antioxidant enzyme due to its catalytic properties during the dismutase reaction of superoxide anion radical. The product of this process is hydrogen peroxide decomposed into water and oxygen due to catalase or gluthathione peroxidase [15].

Catalase can fulfil a dual role. The reaction occurring in the environment with a high concentration of hydrogen peroxide consists in disproportioning. The final product is water $2 \mathrm{H}_{2} \mathrm{O}_{2} \rightarrow \mathrm{O}_{2}+2 \mathrm{H}_{2} \mathrm{O}$.

When the concentration of hydrogen peroxide is low, catalase fulfils the role of peroxidase removing $\mathrm{H}_{2} \mathrm{O}_{2}$ and simultaneously oxidising the organic compound. The inactivation of hydrogen peroxide prevents an occurrence of the Fenton reaction, i.e. transformation of the molecule into the hydroxyl radical.

Gluthathione peroxidase catalyses the reduction of hydrogen peroxide and organic peroxides through reduced gluthathione [16]. The active enzyme centre contains residues of selenocysteine, a cysteine analog, where sulphur atoms have been replaced with selenium atoms.

This unique construction allows initiation of twoelectron gluthathione oxidation without the release of a free thiol radical of gluthathione [11]. In the course of hydrogen peroxide inactivation, a harmful substance is produced - gluthathione disulfide. Gluthathione reductase through NADPH oxidation reproduces the reduced form of gluthathione.

\section{THE APPLICATION OF ANTIOXIDANTS}

Therapy with antioxidants as exogenous dietary supplements aims at preventing or reducing the risk of development of diseases involving the presence of oxygen radicals. Multiple works on the same topic have been published, however their results are inconclusive and this type of effect currently raises controversies.

Free radicals participate in numerous reactions occurring in an organism. They are used as substrates not only in pathological processes but are also indispensable in the course of physiological processes. The prevention of free oxygen radical emergence with the help of antioxidants is not a selective process.

We cannot inhibit these harmful phenomena from occurring in an organism. Moreover, the prevention of pathogenic processes by free radical suppression leads to an occurrence of side effects in the form of stopping physiological reactions aimed at disease eradication.

An example of such a process is the stimulation of the immunological system by free oxygen radicals. Inhibiting of this system impedes the fight against inflammatory and cancerous diseases [17].

\section{ANTIOXIDANTS USED IN TREATMENT OF DISEASES OF THE CIRCULATORY SYSTEM}

Oxidative stress is closely related to metabolic disorders leading to sclerosis. Many positive effects of supplementation with antioxidants as well as their therapeutic effectiveness have been confirmed Nonetheless, the mechanisms through which these antioxidants induce the pro-health effect are not completely explained.

Also, it is not known what kind of reactions occur in an organism following their adoption, as they may produce toxic side effects.

Thus it is necessary to maintain proper caution 
in their use [18]. Goszcz et al. point to the fact that the link between the concentration of antioxidants in the plasma and protection against circulatory diseases is indefinable. The attempts to prove these dependencies are doomed to fail. A large quantity of orally administered antioxidants will be destroyed or extracted before they reach the place where they should bring the potential expected result.

Furthermore, it is possible that it is not the antioxidants supplied with the diet that have the expected cardioprotective effect but other compounds and microelements taken along with them during the application of the so-called "healthy diet"[19].

\section{ANTIOXIDANTS USED IN THE TREATMENT OF CANCEROUS DISEASES}

Certain medicines used in chemotherapy and during radiotherapy involve generation of free radicals. Assumptions are made that the use of antioxidants as adjuvants to treatment or administered with food may lead to the weakening of their efficacy in fighting a cancerous disease.

However, in this case the majority of conducted studies show that antioxidants used in a diet do not influence an anticancer therapy. Moreover, they increase the possibility of killing the affected cells thus diminishing the side effects of the applied therapeutic strategies and protecting the healthy tissue [20].

In the course of type $\mathrm{C}$ chronic viral hepatitis the inclusion of antioxidant therapy has a proven effect in counteracting cirrhosis of the liver. Whereas in the case of other chronic liver diseases, such as non-alcoholic hepatic steatosis it is assumed that the application of such a therapy through the suppression of inflammation and fibrosis can protect against an occurrence of a neoplasm [21].

Martinez-Outschoorn et al. published a work where they prove the anticancer effect of antioxidants on neoplastic cells of breast cancer connected with the mutation in BRCA1 gene. The study was conducted with the use of $\mathrm{N}$-acethylcysteine and TEMPOL [22].

TEMPOL stands for 4-hydroxy-2,2,6,6 tetramethylpiperidine -1 oxyl, a compound catalysing the reaction of disproportioning hydrogen peroxide. A favourable effect of radio-protection on haematopoesis cells was observed in the antioxidant therapy. The effect of oral supplementation of mice with L-selenomethionine, vitamin $\mathrm{C}$, tocopheral, lipoic acid was examined with view to an increased survival rate of animals subjected to radiotherapy.

An increase in the quantities of white blood cells and neutrophils was noted in peripheral blood following 4 and 24 hours from the exposure [23]. Antioxidant therapy implemented after radiation brings much better results when commenced after 24 hours following the exposure.

The improvement was concerned with an increase of survival rate of marrow cells and led to reducing mortality among mice [24]. Upon the analysis of several dozen publications, Mahmoud Rafieian-Kopaie and Hamid Nasri reached the conclusion that the tests conducted on humans do not produce convincing evidence that the administration of antioxidants as a supplement to the selected therapy can reduce the risk of cancer development.

However, several works provided evidence related to an elevated risk of cancer in smokers [25].

\section{OTHER APPLICATIONS OF ANTIOXIDANTS IN THERAPY}

Other reports concerned with the positive effects of therapy with the use of antioxidants include: a study carried out by Reliene R, Schiestl RH, and a publication by J. Reichenbach et al. arguing that the supplementation with $\mathrm{N}$-acethylocysteine and tocopherol leads to an increased life expectancy in patients with ataxia and teleangiectasia, as well as a lower risk of developing lymphoma [26; 27], whereas the use of L-tocopherol in Huntington's disease may delay the loss of motor functions [28].

\section{SUMMARY}

It is vital to develop a good understanding of the pathomechanisms of various diseases, the effect of medicines and antioxidants in order to predict the therapeutic effectiveness. Neurodegenerative diseases involve accumulation of protein aggregates and an occurrence of oxidative stress [29].

The aggregates are removed from the organism through the phenomenon of autophagy, which is closely related to an increase of quantities of free oxygen radicals. The study conducted by B.R. Underwood et al. indicates that the application of autophagy inducing medicines does not have a significant influence on the growth of production of free oxygen radicals but their activity and autophagy is inhibited by antioxidants. It has been proven that a certain level of free oxygen radicals is required for the proper functioning and regulation of the autophagy phenomenon.

Oxidative stress should not be seen as a strictly pathological phenomenon in the context of treatment of neurodegenerative diseases [30]. In the application of an improper therapy the positive effect connected with the use of antioxidants may be reduced by the negative effect of the accumulation of protein aggregates.

Whether the therapy with the use of antioxidants will bring positive or negative effects depends on numerous factors. The decision to include and select a suitable substance with an antioxidant effect requires consideration of such factors as the type of a disease, its stage of development, analysis of pathogenesis, neoplasm type, its molecular type, the thus far applied treatment, prediction of possible interactions, dosage selection [31].

Such a great number of conditions often poses difficulties not only in relation to drug selection but also in determining its effectiveness. 


\section{BIBLIOGRAPHY}

1. Nathan C. Specifity of a third kind: reactive oxygen and nitrogen intermediates in cell signaling. J. Clin. Invest. 2003; 111: 769-778, DOI $10.1172 / \mathrm{JCl} 200318174$

2. Bartosz G. Druga twarz tlenu. Wolne rodniki w przyrodzie. Wyd. 2 zm. Warszawa: Wydawnictwo Naukowe PWN 2004. Polish [Second face of oxygen. Free radical in nature];

3. Ponczek M.B., Wachowicz B.: Oddziaływanie reaktywnych form tlenu i azotu z białkami. Post. Biochem. 2004; 51: 140-145. Polish [Interaction of reactive oxygen and nitrogen species with proteins];

4. Cadenas E. Mitochondrial free radical production and cell signaling. Mol Aspects Med.2004; 25: 17-26, DOI 10.1016/j.mam.2004.02.005;

5. Dröge W. Free radicals in the physiology control of cell function. Physiol. Rev. 2002; 82: 47-95, DOI 10.1152/physrev.00018.2001.

6. Das KC, White CW. Redox system of the cell: possible links and implications. Proc. Nat. Acad. Sci. USA. 2002; 99:9617-9618, DOI 10.1073/pnas.162369199;

7. Pratico D. Alzheimer's disease and oxygen radicals: new insights. Biochem. Pharmacol. 2002; 63: 563-567, DOI 10.1016/S00062952(01)00919-4;

8. Perry G, Nunomura A, Hirai K, Znu X, Perez M, Avila J et al. Is oxidative damage the fundamental pathogenic mechanism of Alzheimer's and other neurodegenerative diseases? Free radic Biol Med 2002; 33: 1475-1479, DOI 10.1016/S0891-5849(02)01113-9;

9. Marnett LJ, Riggins JN, West JD. Endogenous generation of reactive oxidants and electrophiles, and their reactions with DNA and protein I. Clin. Invest.2003; 111: 583-593, DOI: 10.1172/JCI200318022;

10. Valko M, Leibfritz D, Mancol J, Cronin MTD, Mazur M, Telser J. Free radicals and antioxidants in normal physiological functions and human disease. Int. J. Biochem. Cell Biol.2007; 39: 44-84, DOI 10.1016/j.biocel.2006.07.001;

11. Zabłocka A, Janusz M. Dwa oblicza wolnych rodników tlenowych. Post Hig Med. Dosw.2008; 62: 118-124, Polish [The two faces of reactive oxygen species]

12. Karpińska A., Gromadzka G. Stres oksydacyjny I naturalne mechanizmy antyoksydacyjne-znaczenie w procesie neurodegeneracji. Od mechanizmów molekularnych do strategii terapeutycznych. Post Hig Med Dosw 2013; 67:43-53, Polish [Oxidative stress and natural antioxidant mechanisms: the role in neurodegeneration. From molecular mechanisms to therapeutic strategies];

13. Gutowicz M. Wpływ reaktywnych form tlenu na ośrodkowy układ nerwowy. Post Hig Med Dosw 2011; 65: 104-113, Polish [The influence of reactive oxygen species on the central nervous system];

14. Fang YZ, Yang S, Wu G. Free radical, antioxidants and nutrition. Nutrition 2002; 18:872-879, DOI: 10.1016/S0899-9007(02)00916-4;

15. Halliwell B. Oxidative stress and neurodegeneration: where are we now? J. Neurochem. 2006; 97:1634-1658, DOI: 10.1111/j.14714159.2006.03907.x;

16. Pastore A, Federici G, Bertini E, Piemonte F. Analysis of glutathione: implication in redox and detoxification. Clin. Chim. Acta. 2003; 333:19-39, DOI 10.1016/S0009-8981(03)00200-6;

17. Kehrer JP, Klotz LO. Free radicals and related reactive species as mediators of tissue injury and disease: implications for Health. Crit Rev Toxicol. 2015; 45(9):765-98. DOI 10.3109/10408444.2015.1074159;

18. Gregório BM, De Souza DB, de Morais Nascimento FA, Pereira LM, Fernandes-Santos C. The potential role of antioxidants in metabolic syndrome. Curr Pharm Des. 2015 ; 22: 859 - 869 DOI 10.2174/1381612822666151209152352;

19. Goszcz K, Deakin SJ, Duthie GG, Stewart D, Leslie SJ, Megson IL. Antioxidants in Cardiovascular Therapy: Panacea or False Hope? Front Cardiovasc Med. $2015 ; 2: 29$. DOI 10.3389/fcvm.2015.00029;

20. Simone CB, Simone NL, Simone V, Simone CB. Antioxidants and other nutrients do not interfere with chemotherapy or radiation therapy and can increase kill and increase survival, part 1. Altern Ther Health Med. 2007;13(1):22-28;

21. Miyanishi K, Hoki T, Tanaka S, Kato J. Prevention of hepatocellular carcinoma: Focusing on antioxidant therapy. World J Hepatol. 2015; 7(3):593-9. doi: 10.4254/wjh.v7.i3.593;

22. Martinez-Outschoorn UE, Balliet R, Lin Z, Whitaker-Menezes D, Birbe RC, Bombonati A, et al.. BRCA1 mutations drive oxidative stress and glycolysis in the tumor microenvironment: implications for breast cancer prevention with antioxidant therapies. Cell Cycle. 2012; 11(23):4402-13 doi: 10.4161/cc.22776;

23. Wambi C, Sanzari J, Wan XS, Nuth M, Davis J, Ko YH, et al. Dietary Antioxidants Protect Hematopoietic Cells and Improve Animal Survival after Total-Body Irradiation. Radiat Res. 2008; 169(4): 384-396, DOI 10.1667/RR1204.1;

24. Brown SL, Kolozsvary A, Liu J, Jenrow KA, Ryu S, Kim JH. Antioxidant Diet Supplementation Starting 24 Hours after Exposure Reduces Radiation Lethality. Radiat Res. 2010 ; 173(4): 462-468,DOI 10.1667/RR1716.1;

25. Rafieian-Kopaie M, Nasri H. On the Occasion of World Cancer Day 2015; the Possibility of Cancer Prevention or Treatment with Antioxidants: The Ongoing Cancer Prevention Researches .Int J Prev Med. 2015; 6: 108, DOI 10.4103/2008-7802.169077;

26. Reliene R, Schiestl RH. Experimental antioxidant therapy in ataxia telangiectasia. Clin Med Oncol. 2008; 2:431-436;

27. Reichenbach J, Schubert R, Schwan C, Müller K, Böhles HJ, Zielen S. Anti-oxidative capacity in patients with ataxia telangiectasia. Clin Exp Immunol. 1999 ; 117(3): 535-539, DOI10.1046/j.1365-2249.1999.01000.x;

28. Peyser CE, Folstein M, Chase GA, Starkstein S, Brandt J, Cockrell JR,et al. Trial of d-alpha-tocopherol in Huntington's disease. Am J Psychiatry. 1995; 152(12):1771-5, DOI 10.1176/ajp.152.12.1771;

29. Jin H, Kanthasamy A, Ghosh A, Anantharam V, Kalyanaraman B, Kanthasamy AG. Mitochondria-targeted antioxidants for treatment of Parkinson's disease: preclinical and clinical outcomes. Biochim Biophys Acta. 2014; 1842(8): 1282-1294, DOI 10.1016/j.bbadis.2013.09.007;

30. Underwood BR, Imarisio S, Fleming A, Rose C, Krishna G, Heard P, et al. Antioxidants can inhibit basal autophagy and enhance neurodegeneration in models of polyglutamine disease. Hum Mol Genet. 2010; 19(17): 3413-3429, DOI10.1093/hmg/ddq253;

31. Mut-Salud N, Álvarez PJ, Garrido JM, Carrasco E, Aránega A, Rodríguez-Serrano F. Antioxidant Intake and Antitumor Therapy: Toward Nutritional Recommendations for Optimal Results. Med Cell Longev. 2016; 2016: 6719534, DOI 10.1155/2016/6719534.

prof. Agnieszka Pedrycz, M.D., Ph.D.

Department Histology and Embryology, Medical University in Lublin ul. Radziwiłłowska 11 20-080, Lublin e-mail: apw4@wp.pl 